\title{
Effect of High Incubation Temperature on the Blood Parameters of Layer Chicks
}

\section{-Author(s)}

\author{
Sgavioli S! \\ Santos ET" \\ Domingues CHFIII \\ Quadros TCO" \\ Castiblanco DMCII \\ Andrade-Garcia GM \\ Amoroso LIV \\ Nääs IAv \\ Garcia RGv \\ Baraldi-Artoni SM ${ }^{\mathbb{N}}$
}

Professor, Brazil University, 13690-970, Descalvado-SP, Brazil.

" PhD in Animal Science, Department of Morphology and Animal Physiology, São Paulo State University, 14884-900, Jaboticabal-SP, Brazil.

III Post-doctoral program in Agribusiness, Federal University of Grande Dourados - College of Agricultural Sciences, 79.804-970, Dourados-MS, Brazil.

Iv Professor, Department of Morphology and Animal Physiology, São Paulo State University, 14884-900, Jaboticabal-SP, Brazil.

$\checkmark$ Professor, Federal University of Grande Dourados - College of Agricultural Sciences, 79804-970, Dourados-MS, Brazil.

\section{Mail Address}

Corresponding author e-mail address Sarah Sgavioli

Address: Av. Hilário da Silva Passos, 950 16690-970, Descalvado, SP, Brazil Phone: +55 (16) 98116-4120

Email: sarahsgavioli@yahoo.com.br

\section{neywords}

Body weight, cloacal temperature, conductance, hatchability, loss of 'mass.

\section{ABSTRACT}

Adequate environmental temperature control is essential for incubation efficiency. Layer breeder eggs $(n=360)$ were weighed and distributed in a completely randomized experimental design with two treatments, consisting of two incubation temperatures $\left(T 1=37.5^{\circ} \mathrm{C}\right.$, control; and $\mathrm{T} 2=39.0^{\circ} \mathrm{C}$, hot), with two incubators per temperature, and 90 eggs per incubator, totaling 360 eggs. Hatchability, embryo mortality, and chick cloacal and body surface temperatures were not affected by incubation temperature. Eggs incubated at the hot temperature presented greater egg mass loss and higher eggshell conductance than those incubated at the control temperature. Layer chicks derived from eggs incubated at control temperature showed greater absolute weight, yolk-free egg mass, and heavier hearts than those from eggs submitted to heat stress during incubation. The control group presented lower base excess and ionized calcium blood levels. Incubating eggs at temperatures higher than those recommended compromises body and heart development of layer chicks and negatively affects blood ionized calcium availability, and therefore, bone mineralization during embryo development. Efficient temperature control during the incubation of fertile eggs is essential to obtain good quality layer chicks.

\section{INTRODUCTION}

Environmental temperature and humidity, airflow, and egg turning are some of the physical factors that influence incubation (Lourens et al., 2005; King'ori, 2011). Environmental temperature is reported as the most critical physical factor affecting embryo development and hatchability (Yalçin \& Siegel, 2003). Excessive heat inside incubator may reduce hatching efficiency (Willemsen et al.,2011; Boleli \& Queiroz, 2012) and yolk-free body mass (Lourens et al., 2007; Hulet et al., 2007; Leksrisompong et al., 2007), and may affectchick growth after hatching (Tona et al., 2008).

High incubation temperature accelerates embryo metabolism, increases oxygen uptake and carbon dioxide production, which requires cardiovascular and/or hematological adaptations by the embryo. Respiratory, cardiovascular, and metabolic status can be evaluated using blood markers, which are particularly sensitive to temperature changes and are important indicators of the physiological responses of birds to stressors. Thermal stress can lead to changes in hematocrit values (blood erythrocyte levels) and hemoglobin levels (Borges et al., 2003). In addition to metabolic changes, organ weight (particularly heart weight) is reduced when fertile eggs are exposed to high incubation temperatures (Leksrisompong et al., 2007; Lourens et al., 2007). Chicks with low heart weight may present metabolic disorders related to cardiovascular development (Leksrisompong et al., 2007). 
Sgavioli S, Santos ET, Domingues CHF, Quadros TCO, Castiblanco DMC, Andrade-Garcia GM, Amoroso L, Nääs IA, Garcia RG, Baraldi-Artoni SM
Effect of High Incubation Temperature on the Blood Parameters of Layer Chicks
Moreover, high incubation temperatures lead to larger residual yolks, which result in worse chick quality and high mortality rates during the first week of life due to navel/yolk sac infections.

Although current literature provides relevant information on the effects of variations of incubation temperature in broilers (Kidd, 2004; Yahav et al., 2004b; Yalçin et al., 2005; Piestun et al., 2008; Yalçin et al., 2008; Ghonim et al., 2009; Yahav, 2009; Leksrisompong et al., 2007; Willemsen et al., 2011, Druyan et al., 2012; Selim et al., 2012, Loyau et al., 2013), few studies were carried out with layers (Salimet al.,2005; Walstra et al., 2010). The present study aimed at evaluating the influence of high incubation temperature on the incubation and blood parameters, and organs weights of layer chicks.

\section{MATERIALS AND METHODS}

Three hundred and sixty fertile eggs laid by 47-weekold Hisex White layers breeders were weighed and randomly divided in two treatments: incubation at $37.5^{\circ} \mathrm{C}(\mathrm{T} 1=$ control treatment $)$ or at $39.0^{\circ} \mathrm{C}(\mathrm{T} 2=$ hot incubation temperature treatment). Two horizontal incubatorswere usedper treatment (130-egg capacity; Premium Ecológica, model IP-130, Brazil), with 90 eggs each. The incubators were equipped with automatic temperature control, and the eggs were turned every two hours. Relative humidity was maintained at $60 \%$ until the eggs were transferred to the hatcher (day19 of incubation), whereair relative humidity was increased to $70 \%$ and air temperature was reduced in $1{ }^{\circ} \mathrm{C}$.

Hatchability, embryo mortality, egg mass loss, eggshell conductance, chick body surface temperature, chick cloacal temperature, chick relative weight, and absolute and relative weights of the liver, yolk sac, heart and gizzard, and blood parameters were analyzed.

The experiment was carried at the Laboratory of Avian Sciences of Jaboticabal Campus, at the State University of São Paulo, Brazil. All procedures were approved by the Ethics Committee of that university (Protocol number 7377/2010).

\section{Hatchability and embryo mortality}

Hatchability was defined as the number of chicks that hatched divided by the number of fertile eggs incubated. Embryo mortality was classified as early ( 1 to 7 days), intermediate (8 to 14 days), or late (15 to 21 days). Hatchability and embryo mortality were assessed in all the incubated eggs.

All studied variables below were measured 30 minutes after hatching in eight birds per treatment.

\section{Body surface temperature, cloacal temperature, egg mass loss, and eggshell conductance}

Wing, head, leg, and back surface temperatures were recorded using an infrared thermometer (Instrutemp, ITTI 380) to obtain the average body surface temperature (T). T was calculated using the following equation (1), according to Richard (1971).

$$
\begin{gathered}
\mathrm{T}=\left(0.12 \times \mathrm{T}_{\text {wing }}\right)+\left(0.03 \times \mathrm{T}_{\text {head }}\right)+\left(0.15 \times \mathrm{T}_{\text {leg }}\right)+ \\
\left(0.70 \times \mathrm{T}_{\text {back }}\right)
\end{gathered}
$$

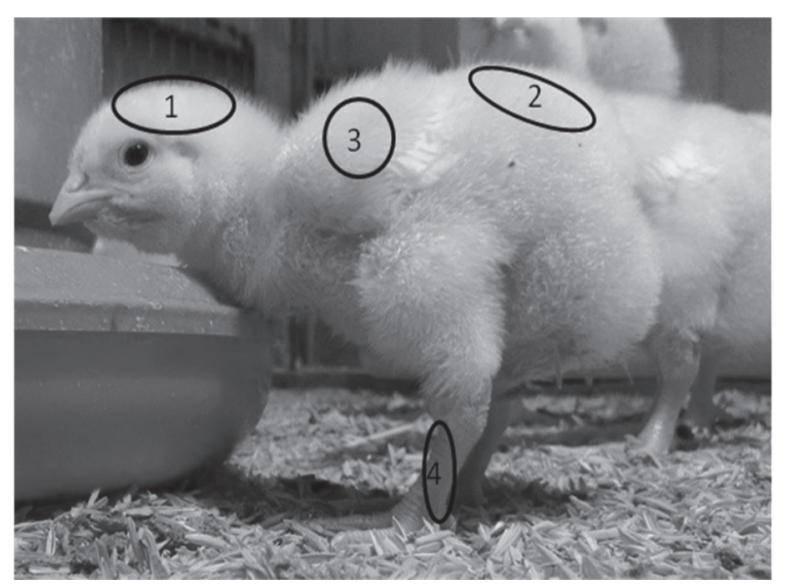

Figure 1 - Example of selection of specific areas of a pinto (1: head; 2: back; 3: wing; 4: leg).

The temperatures were measured at a distance of two mm from the skin of the chick. Cloacal temperature was measured using the sensor of a tele-thermometer (Max-Min Thermo Hygro) placed three cm inside the cloaca. Cloacal temperature was used for correcting blood $\mathrm{pH}$, partial carbon dioxide pressure, and partial oxygen pressure blood values obtained using aportable blood analyzer (i-STAT ${ }^{\circledR} \mathrm{Co}$., Abbott Laboratories, USA; cartridge $\left.\mathrm{Cg} 8+^{\circledR}\right)$. Temperatures were measured immediately after chicks were removed from the hatcher.

Egg mass loss was calculated as the difference between egg weight at the onset of incubation and on day 19 of incubation, and expressed as a percentage. Eggshell conductance was calculated as egg mass loss (g) until the day of transference divided by steam saturation pressure $\left(23.86 \mathrm{~mm} / \mathrm{Hg}\right.$ at $\left.25^{\circ} \mathrm{C}\right)$.

\section{Organ weights and blood parameters}

Chicks were individually weighed on a digital scale after the down dried, and their relative body weight $(\%)$ and relative yolk-free body mass were calculated (\%) as a percentage of egg weight ( $\mathrm{g}$ ).

Absolute and relative weights of the liver, yolk sac, heart, and gizzard, were determined at hatching 
Sgavioli S, Santos ET, Domingues CHF, Quadros TCO, Castiblanco DMC,

Andrade-Garcia GM, Amoroso L,

Nääs IA, Garcia RG, Baraldi-Artoni SM in eight chicks per treatment. Chicks were sacrificed by cervical dislocation. Organ weight was calculated relative to individual chick body weight.

Arterial blood (1 mL) samples were collected directly from the aorta using a syringe containing heparin. Blood analyses were performed using a portable analyzer (i-STAT ${ }^{\circledR}$ Co., Abbott Laboratories, USA; cartridge Cg8 $\left.+{ }^{\circledR}\right)$. Hematocrit (HCT, \% PCV), hemoglobin ( $\mathrm{HGB}, \mathrm{g} / \mathrm{dL}), \mathrm{pH}$, partial carbon dioxide pressure $\left(\mathrm{pCO}_{2} \mathrm{mmHg}\right)$, partial oxygen pressure $\left(\mathrm{pO}_{2} \mathrm{mmHg}\right)$, base excess (BEecf, $\mathrm{mmol} / \mathrm{L}$ ), total carbon dioxide $\left(\mathrm{TCO}_{2}, \mathrm{mmol} / \mathrm{L}\right)$, oxygen saturation $\left(\mathrm{sO}_{2}, \%\right)$, sodium concentration $\left(\mathrm{Na}^{+}, \mathrm{mmol} / \mathrm{L}\right)$, potassium concentration $\left(\mathrm{K}^{+}, \mathrm{mmol} / \mathrm{L}\right)$, ionized calcium concentration (Cai, $\mathrm{mmol} / \mathrm{L})$, bicarbonate $\left(\mathrm{HCO}_{3}^{-}, \mathrm{mmol} / \mathrm{L}\right)$, and glucose $(\mathrm{mg} / \mathrm{dL})$ blood levels were analyzed. The analyzeswere performed in eight chicks per treatment.

\section{Statistical analysis}

The effects of incubation temperature $\left(37.5^{\circ} \mathrm{C}\right.$ and $39.0^{\circ} \mathrm{C}$ ) on all studied parameters were statistically analyzed using the model described in Eq. 1.

$$
Y_{i j}=\mu+T_{i}+e_{i j}
$$

where $Y=$ the studied parameters, $\mu=$ the mean value of the parameter, $\mathrm{T}=$ effect of the $\mathrm{i}^{\text {th }}$ treatment $\left(37.5^{\circ} \mathrm{C}\right.$ or $\left.39.0^{\circ} \mathrm{C}\right)$, and $\mathrm{e}_{\mathrm{ijk}}=$ the residual error. Data were subjected to analysis of variance using the General Linear Model of SAS ${ }^{\circledR}$ program (SAS Institute, 2002). When significant effects at $5 \%$ probability level were detected, means were compared by the test of Tukey.

\section{RESULTS}

\section{Hatchability and embryo mortality}

Incubation temperature did not influence hatchability or early, intermediate, late, and total embryo mortality ( $p>0.05$; Table 1 ).

\section{Cloacal temperature, body surface temperature, egg mass loss, and the eggshell conductance}

The evaluated incubation temperatures did not affect chick cloacal or body surface temperature ( $p>0.05$ ). However, $T 2$ eggs showed greater egg mass loss and higher eggshell conductance $(p<0.05$; Table 1$)$ than the control group.

\section{Organ weight}

Relative body weight was not different between treatments $(p>0.05)$. However, chicks of the control group (T1) presented heavier absolute and relative yolk-free body mass and heavier hearts $(p<0.05$; Table 2) thanT2 birds.

\section{Blood parameters}

Blood BEecf was lower in T2 chicks than in T1 chicks ( $p<0.05$; Table 3 ). However, this larger base loss did not result in HGB or HCT increase ( $p>0.05$; Table 4). Moreover, the treatments did not affect blood $\mathrm{pH}, \mathrm{pCO}_{2}, \mathrm{pO}_{2}, \mathrm{TCO}_{2}, \mathrm{sO}_{2}$, or $\mathrm{HCO}_{3}^{-}(\mathrm{p}>0.05)$. Ionized calcium concentration was lower in the blood of the chicks incubated at T2 ( $p<0.05$; Table 5$)$ than at T1. As for the other evaluated ions or blood glucose levels,

Table 1 - Effect of incubation temperature on embryo mortality, hatchability, loss of egg mass and the eggshell conductance.

\begin{tabular}{|c|c|c|c|c|c|c|c|}
\hline \multirow{2}{*}{ Incubation temperature } & \multicolumn{3}{|c|}{ Embryo mortality (day)* (\%) } & \multirow{2}{*}{$\begin{array}{c}\text { Total mortality* } \\
(\%)\end{array}$} & \multirow{2}{*}{$\begin{array}{l}\text { Hatchability } \\
(\%)\end{array}$} & \multirow{2}{*}{ Loss of mass (\%) } & \multirow{2}{*}{ Conductance } \\
\hline & $0-7$ & $8-14$ & $15-21$ & & & & \\
\hline $37.5^{\circ} \mathrm{C}$ & $4.18 \pm 2.82$ & $0.50 \pm 0.99$ & $5.43 \pm 2.85$ & $10.11 \pm 5.36$ & $89.89 \pm 5.36$ & $10.11 \pm 2.01 a$ & $0.42 \pm 0.09 a$ \\
\hline $39.0^{\circ} \mathrm{C}$ & $9.35 \pm 5.18$ & $0.00 \pm 0.00$ & $9.19 \pm 5.76$ & $18.54 \pm 8.95$ & $81.46 \pm 8.95$ & $11.91 \pm 1.91 b$ & $0.50 \pm 0.08 b$ \\
\hline$p$-value & 0.201 & 0.437 & 0.4094 & 0.253 & 0.177 & $<0.0001$ & $<0.0001$ \\
\hline CV (\%) & 35.23 & 62.15 & 25.94 & 22.82 & 8.14 & 17.80 & 17.77 \\
\hline
\end{tabular}

\pm standard deviation; CV: Coefficient of variation. ${ }^{*}$ ANOVA based on transformed data $y=\log (y+1.5)$.

Table 2 - Effect of incubation temperature on an absolute and relative weight of post-hatch chicks organs.

\begin{tabular}{|c|c|c|c|c|c|c|c|c|c|}
\hline \multirow[t]{2}{*}{$\begin{array}{l}\text { Incubation } \\
\text { temperature }\end{array}$} & BW & $\begin{array}{c}\text { BW without the } \\
\text { yolk sac }\end{array}$ & Yolk sac & Heart & Liver & $\begin{array}{l}\text { BW without } \\
\text { the yolk sac }\end{array}$ & Yolk sac & Heart & Liver \\
\hline & $(\%)$ & \multicolumn{4}{|c|}{ (g) } & \multicolumn{4}{|c|}{ (\%) } \\
\hline $37.5^{\circ} \mathrm{C}$ & $69.68 \pm 2.40$ & $33.67 \pm 1.35 a$ & $6.06 \pm 0.78$ & $0.37 \pm 0.04 a$ & $0.89 \pm 0.06$ & $58.78 \pm 1.64 a$ & $14.83 \pm 1.69$ & $0.90 \pm 0.11 \mathrm{a}$ & $2.17 \pm 0.20$ \\
\hline $39.0^{\circ} \mathrm{C}$ & $69.26 \pm 2.31$ & $32.00 \pm 1.77 b$ & $5.95 \pm 1.10$ & $0.28 \pm 0.04 b$ & $0.80 \pm 0.13$ & $56.00 \pm 1.54 b$ & $14.96 \pm 2.54$ & $0.71 \pm 0.07 b$ & $2.02 \pm 0.28$ \\
\hline$p$-value & 0.7492 & 0.0291 & 0.8206 & 0.0002 & 0.0918 & 0.0109 & 0.9243 & 0.0003 & 0.1596 \\
\hline CV (\%) & 3.37 & 4.79 & 15.84 & 12.22 & 12.34 & 2.77 & 14.48 & 11.68 & 11.49 \\
\hline
\end{tabular}

BW: body weight; \pm standard deviation; CV: Coefficient of variation; a-b: means followed by different letters in columns differ significantly at $5 \%$ probability (Tukey's test). 
Sgavioli S, Santos ET, Domingues CHF,

Quadros TCO, Castiblanco DMC,

Andrade-Garcia GM, Amoroso L,

Nääs IA, Garcia RG, Baraldi-Artoni SM
Effect of High Incubation Temperature on the Blood

Parameters of Layer Chicks

Table 3 - Effect of incubation temperature on cloacal temperature, body surface temperature and blood gases in post-hatch chicks.

\begin{tabular}{lccccccccc}
\hline $\begin{array}{l}\text { Incubation } \\
\text { temperature }\end{array}$ & $\begin{array}{c}\text { Cloacal } \\
\text { temperature } \\
\left({ }^{\circ} \mathrm{C}\right)\end{array}$ & $\begin{array}{c}\text { Body surface } \\
\text { temperature } \\
\left({ }^{\circ} \mathrm{C}\right)\end{array}$ & $\mathrm{pH}$ & $\begin{array}{c}\mathrm{pCO}_{2} \\
(\mathrm{mmHg})\end{array}$ & $\begin{array}{c}\mathrm{pO}_{2} \\
(\mathrm{mmHg})\end{array}$ & $\begin{array}{c}\mathrm{BEecf} \\
(\mathrm{mmol} / \mathrm{l})\end{array}$ & $\begin{array}{c}\mathrm{TCO}_{2} \\
(\mathrm{mmol} / \mathrm{l})\end{array}$ & $\begin{array}{c}\mathrm{SO}_{2} \\
(\%)\end{array}$ & $\begin{array}{c}\mathrm{HCO}_{3} \\
(\mathrm{mmo} / /)\end{array}$ \\
\hline $37.5^{\circ} \mathrm{C}$ & $37.98 \pm 084$ & $26.72 \pm 0.43$ & $7.46 \pm 0.06$ & $26.62 \pm 4.47$ & $40.78 \pm 6.76$ & $2.22 \pm 6.48 \mathrm{a}$ & $20.00 \pm 4.47$ & $75.67 \pm 5.19$ & $19.18 \pm 4.33$ \\
$39.0^{\circ} \mathrm{C}$ & $38.23 \pm 0.78$ & $27.88 \pm 1.47$ & $7.43 \pm 0.04$ & $25.11 \pm 4.09$ & $42.78 \pm 5.78$ & $-7.22 \pm 3.27 \mathrm{~b}$ & $17.56 \pm 2.79$ & $77.22 \pm 10.57$ & $16.74 \pm 2.92$ \\
\hline $\mathrm{p}$-value & 0.498 & 0.052 & 0.2978 & 0.4647 & 0.5096 & 0.0013 & 0.1831 & 0.2978 & 0.1810 \\
$\mathrm{CV}(\%)$ & 2.11 & 3.83 & 0.71 & 16.55 & 15.06 & -205.20 & 18.85 & 10.89 & 20.55 \\
\hline
\end{tabular}

\pm standard deviation; CV: Coefficient of variation; a-b: means followed by different letters in columns differ significantly at $5 \%$ probability (Tukey's test).

Table 4 - Effect of incubation temperature on erythrocyte variables in chicks.

\begin{tabular}{lcc}
\hline Incubation temperature & $\mathrm{HCT}(\% \mathrm{PCV})$ & $\mathrm{HGB} \times(\mathrm{g} / \mathrm{dL})$ \\
\hline $37.5^{\circ} \mathrm{C}$ & $17.29 \pm 3.95$ & $5.89 \pm 1.34$ \\
$39.0^{\circ} \mathrm{C}$ & $15.88 \pm 3.04$ & $5.40 \pm 1.05$ \\
\hline p-value & 0.4487 & 0.466 \\
$\mathrm{CV}(\%)$ & 21.11 & 21.25 \\
\hline
\end{tabular}

\pm standard deviation; CV: Coefficient of variation.

no difference was found between T1 and T2 ( $p>0.05$; Table 5).

\section{DISCUSSION}

The present study aimed at investigating the effect of high incubation temperature on the blood parameters of layer. The use of thermal manipulation (TM) during incubation in broilers indicates that incubation temperature is a critical factor in the incubation process, affecting hatching and embryo quality (Yalçin \& Siegel, 2003, Willemsen et al., 2011; Boleli \& Queiroz, 2012, Ferreira et al., 2015). However, there are few literature reports on TM applied to layer chicks (Salimet al., 2005; Walstra et al., 2010).

Eggshell conductance allows the gas exchange between the egg and the incubation environment, and allows embryo water and metabolic heat loss (Campos et al., 2003; Hamidu et al., 2007). High eggshell conductance leads to high water and heat loss through evaporation. In the present study, the higher mass loss of the eggs incubated at $39.0^{\circ} \mathrm{C}$ was probably due to higher water evaporation from the embryos (Shafey, 2002). Fertile eggs absorb heat from the incubator during the first half of the incubation period, whenthe embryo's temperature is lower than that of the incubator. However, embryosalso lose heat during the second half of the incubation, when their metabolic rate and heat production increases (Meijerhof, 1999; Tazawa \& Whittow, 2000). The greater egg mass loss of the eggs incubated in thehot environment in the current experiment was due to higher heat loss compared to those of the control treatment, as a result of their higher shell conductance.

Excessive embryo water loss (>14\%) causes death by dehydration (Romanoff, 1930). In the present study, eggs incubated at $39.0^{\circ} \mathrm{C}$ lost $11.91 \%$ of their egg mass, which value isvery close to the rates reported for fertile broiler eggs incubated at $37.8^{\circ} \mathrm{C}$ (Rosa et al., 2002). Therefore, the egg mass loss obtained in the current study was within the acceptable limit.

Egg mass loss at the time of egg transference to the hatcher was used to determine the degree of embryo development,as it is associated with hatchling weight (Shafey, 2002). In the present study, the significant mass loss of the eggs incubated in the hot environment resulted in lower yolk-free body mass at hatch. This result is consistent with previous research reports on the effects of high incubation temperatures on broiler chicks (Lourens et al., 2007; Molenaar et al., 2007).

Yolk-free body mass is a better indicator of broiler development than body weight, because the latter included the weight of the residual, not yet metabolized yolk (Wolanski et al., 2004). In the present study, the quality of the chicks derived from eggs incubated at high incubation temperature was worse compared with

Table 5 - Effect of incubation temperature on $\mathrm{Na}^{+}, \mathrm{K}^{+}$, ionized $\mathrm{Ca}$ and glucose in the blood of chicks.

\begin{tabular}{lcccc}
\hline Incubation temperature & $\begin{array}{c}\mathrm{Na}^{+} \\
(\mathrm{mmol} / \mathrm{l})\end{array}$ & $\begin{array}{c}\mathrm{K}^{+} \\
(\mathrm{mmol} / \mathrm{l})\end{array}$ & $\begin{array}{c}\text { lonized Ca } \\
(\mathrm{mmol} / \mathrm{l})\end{array}$ & $\begin{array}{c}\mathrm{Glucose} \\
(\mathrm{mg} / \mathrm{dL})\end{array}$ \\
\hline $37.5^{\circ} \mathrm{C}$ & $133.67 \pm 3.11$ & $4.17 \pm 0.51$ & $0.953 \pm 0.21 \mathrm{a}$ & $187.33 \pm 17.31$ \\
$39.0^{\circ} \mathrm{C}$ & $134.79 \pm 2.96$ & $3.94 \pm 0.62$ & $0.699 \pm 0.21 \mathrm{~b}$ & $184.89 \pm 25.79$ \\
\hline $\mathrm{p}$-value & 0.4490 & 0.4161 & 0.0489 & 0.8163 \\
$\mathrm{CV}(\%)$ & 2.26 & 13.92 & 25.35 & 11.80 \\
\hline
\end{tabular}

\pm standard deviation; CV: Coefficient of variation; a-b: means followed by different letters in columns differ significantly at $5 \%$ probability (Tukey's test). 
Sgavioli S, Santos ET, Domingues CHF, Quadros TCO, Castiblanco DMC, Andrade-Garcia GM, Amoroso L, Nääs IA, Garcia RG, Baraldi-Artoni SM
Effect of High Incubation Temperature on the Blood Parameters of Layer Chicks those incubated at standard temperature, as shown by their lower yolk-free body mass, consistent with the previous reports of Lourens et al. $(2005,2007)$, Joseph et al. (2006), Leksrisompong et al. (2007), Piestun et al. (2009), and Molenaar et al. (2011).

In the current study, layer chicks from eggs incubated at $39.0{ }^{\circ} \mathrm{C}$ showed lower absolute and relative heart weights than those incubated at standard temperature. According to Lilja \& Olsson (1987), the ontogenetic development of birds after hatching is characterized by the preferential growth of the heart, intestines, and liver. In the present experiment, incubation temperature manipulation resulted heart hypoplasia, but did not affect the weight of the other evaluated organs, indicating that high incubation temperatures may affect individual organs differently. Heart hypoplasia reduces oxygen supply to the tissues, and may consequently impair layer body development and cause metabolic disorders. For instance, broilers derived from eggs incubated at high temperature presented higher incidence of ascites during the growout period compared with those incubated at standard temperature (Molenaar et al., 2011).

Low hatching rates have been reported in broiler eggs exposed to long (Morita et al., 2010) or short periods of hyperthermia (French, 2000).Although egg mass loss and eggshell conductance were higher in the eggs incubated at high temperature, in the present experiment, hatchability and embryo mortality were not affected. This mayindicate that continuous incubation at $39.0^{\circ} \mathrm{Cmay}$ not be a limiting thermal factor for embryo development. Such results are consistent with previous reports of Sgavioli et al. (2013) in fertile broiler eggs incubated at $39.0^{\circ} \mathrm{C}$, and of Walstra et al. (2010) in layer chicks. Studies on TM during broiler embryogenesis present hatching results that may be related to the temperature applied and its duration (Yahav et al., 2004a, b.; Collin et al., 2005). Laying hens embryos are probably more resistant to heat stress than broilers embryos due to their lower metabolic and body growth rates (Macari et al., 2002).

Hyperventilation caused by heat stress results severe loss of carbon dioxide by the lungs, consequently reducing blood bicarbonate levels (Smith \& Teeter, 1987; Balnave \& Gornan, 1993). Therefore, reductions in BEecf may disturb the acid-base balance as a result of heat stress (Borges et al., 2003). Blood BEecf values were lower in the layer chicks from eggs incubated at hot environmental temperature $(p<0.05)$. Embryos submitted to thermal challenge lost more bases than those at the control (Table 4). Values lower than $3 \mathrm{mEq} / \mathrm{L}$ indicate base loss due to primary metabolic disorder (metabolic acidosis). They may also result from the renal excretion of $\mathrm{HCO}_{3}$ to compensate the $\mathrm{pCO}_{2}$ reduction caused by respiratory alkalosis in order to reestablish normal blood $\mathrm{pH}$ values. Arterial blood $\mathrm{pH}, \mathrm{CO}_{2}$ partial pressure, and $\mathrm{O}_{2}$ saturation pressure were not influenced by the treatments, and therefore, metabolic rate and respiratory physiology changes of embryos submitted to thermal manipulation was excluded in the present study. These results are different fromthe findings of Yalçin et al. (2008), Willemsen et al. (2011), and Walstra et al. (2010), who observed metabolic alkalosis during embryogenesis caused by TM.

In the current study, the high base loss values did not result in HGB or HCT increases which function as bases and contribute to the buffer system. These findings indicate that, despite the changes in the acidbase balance of layer hatchlings (low BEecf), there was no immediate metabolic acidosis, as detected by the erythrocyte parameters.

Birds submitted to heat stress commonly develop respiratory alkalosis, followed by metabolic acidosis as a compensatory response to the drop in $\mathrm{pCO}_{2}$ (Borges et al., 2003). Thismetabolism imbalance leads to bone mineral resorption and calcium excretion by the kidneys (Bushinsky, 1994). Calcium is present in three forms in the blood: calcium bound to protein, calcium complexed with organic acids, and free ionized calcium, which is used for bone mineralization. Heat stress results in blood electrolyte and mineral imbalances, which cause the calcium previously available for bone mineralization to form complexes with organic acids (Macari et al., 2002). Therefore, the observed reduction in ionized $\mathrm{Ca}$ in the blood of chicks from eggs incubated at $39.0{ }^{\circ} \mathrm{C}$ demonstrates that less free calcium was available for bone development and mineralization, which could possibly compromise their subsequent growth. Moreover, there may be less calcium available in the bones for eggshell formation. Therefore, despite the lack of evidence of metabolic acidosis as detected by erythrocyte parameters, the high incubation temperature induced the formation of calcium complexesand reduced the blood concentration of ionized calcium.

Poultry exposed to heat stress need to increase body heat loss and reduce metabolic heat production. When body surface temperature increases, blood flow to the surface increases to allow heat dissipation (Macari et al., 2002). The high incubation temperature did not influence chick body surface or cloacal rectal temperature at hatch, indicating no increase in heat loss at in chicks incubated at $39.0^{\circ} \mathrm{C}$. 
Sgavioli S, Santos ET, Domingues CHF,

Quadros TCO, Castiblanco DMC,

Andrade-Garcia GM, Amoroso L,

Nääs IA, Garcia RG, Baraldi-Artoni SM
Effect of High Incubation Temperature on the Blood

Parameters of Layer Chicks
The results of the present study may contribute to a better understanding of the effects of thermal manipulation during incubation on the development of layer chicks.

\section{CONCLUSIONS}

Incubating eggs at $39{ }^{\circ} \mathrm{C}$ compromises the body and heart development of layer chicks and reduces the availability of blood ionized calcium for bone mineralization during embryo development. Effective temperature control during the incubation of fertile layer eggs is essential to obtain good chick quality. Incubation temperatures above those recommended for a specific strain may compromise embryo development and consequently their post-hatch performance.

\section{REFERENCES}

Balnave D, Gorman I. A role for sodium-bicarbonate supplements for growing broilers at high-temperatures. Worlds Poultry Science Journal 1993;49:236-241.

Boleli IC, Queiroz SA. Effects of incubation temperature and relative humidity on embryonic development in eggs of red-winged tinamou (Rhynchotus rufescens). International JouRnal of Poultry Science 2012;11(8):517-523

Borges SA, Fischer da Silva AV, Ariki J, Hooge DM, Cummings KR. Dietary electrolyte balance for broiler chickens exposed to thermoneutral or heat-stress environments. Poultry Science 2003;82:428-435.

Bushinsky DA. Calcium and phosphorus homeostasis: primer on kidney disease. New York: Academic Press; 1994. p.406-413.

Campos EJ, Santos JEC. O efeito de linhagens sobre o desenvolvimento embrionário. In: Macari M, Gonzales E, editors. Manejo da Incubação. Campinas: Facta; 2003. p. 97-124.

Collin A, Picard M, Yahav S. The effect of duration of thermal manipulation during broiler chick's embryogenesis on body weight and body temperature of post hatched chicks. Animal Research 2005;54:105112.

Druyan S, Piestun Y, Yahav S. Heat stress in domestic fowl: genetic and physiological aspects. In: Josipovic S, Ludwigm E, editors. Heat stress: causes, treatment and prevention, New York: Nova Science Publishers; 2012. p. 1-30.

Ferreira IB, Junior JBM, Sgavioli S, Vicentini TI, Morita VS, Boleli IC. Vitamin $C$ prevents the effects of high rearing temperatures on the quality of broiler thigh meat. Poultry Science 2015;94:841-51.

French NA. Effect of short periods of high incubation temperature on hatchability and incidence of embryo pathology of turkey eggs. British Poultry Science 2000;41:377-382

Ghonim AIA, Awad AL, Fattouh MHA, El-Shhat AM. Comparative study of ascorbic acid treatment methods on hatchability traits and growth performance of ducklings. Egypt Poultry Science Journal 2009;29:10851099.

Hamidu JA, Fasenko GM, Feddes JJR, O'Dea EE, Ouellette CA, Wineland $\mathrm{MJ}$, et al. The effect of broiler breeder genetic strain and parent flock age on eggshell conductance and embryonic metabolism. Poultry Science 2007;86:2420-2432.
Hulet R, Gladys G, Hill D, Meijerhof R, El Shiekh T. Influence of eggshell embryonic incubation temperature and broiler breeder flock age on posthatch growth performance and carcass characteristics. Poultry Science2007;86:408-412

Joseph NS, Lourens A, Moran Jr ET. The effects of suboptimal eggshell temperature during incubation on broiler chick quality, live performance, and further processing yield. Poultry Science 2006;85:932-938.

Kidd MT. Nutritional modulation of immune function in broilers. Poultry Science 2004;83:650- 657

King 'Ori AM. Review of the factors influence eggs fertility and hatchability in poultry. International Journal of Poultry Science 2011;10(6):483-492.

Leksrisompong N, Romero-Sanchez H, Plumstead PW, Brannan KE, Brake J. Broiler incubation. 1. Effect of elevated temperature during late incubation on body weight and organs of chicks. Poultry Science 2007;86:2685-2691.

Lilja C, Olsson N. Changes in embryonic development associated with long-term selection for high growth rate in Japanese quail. Growth 1987;51:301-308.

Lourens A, Van Den Brand H, Heetkamp MJW, Meijerhof R, Kemp B. Effects of eggshell temperature and oxygen concentration on embryo growth and metabolism during incubation. Poultry Science 2007;86:11942199

Lourens A, Van Den Brand H, Meijerhof R and Kemp B. Effect of eggshell temperature during incubation on embryo development, hatchability, and posthatch development. Poultry Science 2005; 84:914-920.

Loyau T, Berri C, Bedrani L, Métayer-Coustard S, Praud C, Duclos MJ, et al. Embryo thermal manipulations modifies the physiology and body compositions of broiler chickens reared in floor pens without altering breast meat processing quality. Journal Animal Science 2013;91:36743685

Macari M, Furlan RL, Gonzalez E. Fisiologia aviária aplicada a frangos de corte. Jaboticabal: Funep;2002. p.375

Meijerhof R. Embryo temperature is the key factor in incubation. Worlds Poultry Science Journal 1999;15:42-43

Molenaar R, Anker Van Den I, Meijerhof R, Kemp B, Brand Van Den H. Effect of eggshell temperature and oxygen concentration during incubation on the developmental and physiological status of broiler hatchlings in the perinatal period. Poultry Science 2007;90:1257-1266

Molenaar R, Meijerhof R, Kemp B, Van Den Brand H. The effect of eggshell temperature on malpositions, protein energy and heart weight in broiler embryos. Proceedings of the 4th Workshop on Fundamental Physiology and Perinatal Development in Poultry; 2009. Bratislava. Slovakia; 2009. p.31

Molenaar R, Hulet R, Meijerhof R, Maatjens CM, Kemp B, Van den Brand $H$. High eggshell temperatures during incubation decrease growth performance and increase the incidence of ascites in broiler chickens. Poultry Science 2011;90:624-632

Morita VS, Boleli IC, Oliveira JA. Hematological and incubation parameters of chicks from young breeders eggs: variation with sex and incubation temperature. International Journal of Poultry Science 2010;9(6):606612.

Piestun Y, Halevy O, Yahav S. Thermal manipulations of broiler embryos, the effect on thermoregulation and development during embryogenesis. Poultry Science 2009;88: 2677-2688

Piestun Y, Shinder D, Ruzal M, Halevy O, Brake J, Yahav S. Thermal manipulations in late-term chick embryos have immediate and longer term effects on myoblast proliferation and skeletal muscle hypertrophy. Poultry Science 2008;87:1516-1525. 
Sgavioli S, Santos ET, Domingues CHF,

Quadros TCO, Castiblanco DMC,

Andrade-Garcia GM, Amoroso L,

Nääs IA, Garcia RG, Baraldi-Artoni SM
Richards SA. The significance of changes in the temperature of the skin and body core of the chicken in the regulation of heat loss. The Journal of Physiology 1971;216:1-10

Romanoff AL. Biochemistry and biophysics of the development hen's egg. Memory Cornell University Agriculture Experiment Station 1930;132:127.

Rosa PS, Guidoni AL, Lima IL. Influência da temperatura de incubação em ovos de matrizes de corte com diferentes idades e classificados por peso sobre os resultados de incubação. Revista Brasileira de Zootecnia 2002;31(2):1011-1016.

Salim HE, Agma A, Senkoylu N. Effects of storage time and temperature on egg quality in old laying hens. The Journalof Applied Poultry Research 2005; 14:3:548-553.

SAS Institute. SAS proprietary software release 9.2. Cary: SAS Institute; 2002.

Selim SA, Gaafar K, MandEl-ballal SS. Influence of in-ovo administration with vitamin $\mathrm{E}$ and ascorbic acid on theperformance of Muscovy ducks. Emirate Journal of Food and Agriculture 2012;24:264-271.

Sgavioli S, Almeida de VR, Praes MFFM, Vicentini TI, Matos Júnior JB, Morita $\checkmark$ de $S$, et al. Effects of intra-egg injection of vitamin $C$ on the eggshell mineral absorption, embryo mortality and hematological variables in chicks at hot incubation temperature. International Journal of Poultry Science 2013;12(8):456-463

Shafey TM. Egg shell conductance, embryonic growth, hatchability and embryonic mortality of broiler breeder eggs dipped into ascorbic acid solution. British Poultry Science 2002;43:135-140.

Smith MO, Teeter RG. Effect of ammonium-chloride and $\mathrm{kcl}$ on survival of broiler chicks during acute heat-stress. Nutrition Research 1987;7:677681.

Tazawa H, Whittow GC. Incubation physiology. In: Whittow GC, editor. Sturkie's avian physiology. 5thed. New York: Academic Press; 2000. p.617-634.

Tona K, Onagbesan O, Bruggeman V, Collin A, Berri C, Duclos M, et al. Effects of heat conditioning at $d 16$ to 18 of incubation or during early broiler rearing on embryo physiology, posthatch growth performance and heat tolerance. Archives für Geflügelkunde 2008;72:75-83.
Walstra I, ten Napel J, Kemp B, Van Den Brand H. Temperature manipulation during layer chick embryogenesis. Poultry Science 2010;89:1502-1508.

Willemsen $H$, Willems $Y$, Franssens E, Wang Y, Decuypere E. Intermittent thermal manipulations of broiler embryos during late incubation and their immediate effect on the embryonic development and hatching process. Poultry Science 2011;90:1302-1312

Wolanski NJ, Luiten EJ, Meijerhof R, Vereijken ALJ. Yolk utilisation and chick length as parameters for embryo development. Avian and Poultry Biolology Reviews 2004;15:233-234.

Yahav S. Alleviating heat stress in domestic fowl - different strategies. Worlds Poultry Science Journal 2009;65:719-732.

Yahav S, Collin A, Shinder D, Picard M. Thermal manipulations during broiler chick's embryogenesis, the effect of timing and temperature. Poultry Science 2004a;83:1959-1963.

Yahav S, Sasson-Rath R, Shinder D. The effect of thermal manipulations during embryogenesis of broiler chicks (Gallus domesticus) on hatchability, body weight and thermoregulation after hatch. Journal of Thermal Biology 2004b;29:245-250.

Yahav S, Shinder D, Ruzal M, Giloh M, Piestun Y. Controlling body temperature - the opportunities for highly productive domestic fowl. In: Cisneiros AB, Gois, BL, editors. Body temperature control. New York: Nova Science Publishers; 2009. p.65-98.

Yalçin S, Siegel PB. Developmental stability of broiler embryos in relation to length of egg storage prior to incubation. The Journal of Poultry Science 2003:40:298-308.

Yalçin S, Cabuk M, Bruggeman V, Babacanoglu E, Buyse J, Decuypere E et al. Acclimation to heat during incubation: 3. Body weight, cloacal temperatures, and blood acid-base balance in broilers exposed to daily high temperatures. Poultry Science 2008;87:2671-2677.

Yalçin S, Özkan S, Çabuk M, Buyse J, Decuypere E, Siegel PB. Pre- and postnatal conditioning induced thermo tolerance on body weight, physiological responses and relative asymmetry of broilers originating from young and old breeder flocks. Poultry Science 2005;84:967-976. 
